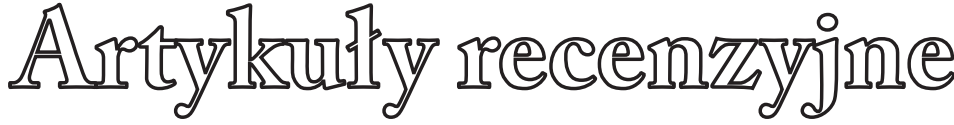

Liturgia Sacra 24 (2018), nr 1, s. 267-272

DOI: $10.25167 / \mathrm{LitS} / 24(2018) 1 / 267-272$

StANISŁAW RABIEJ

Wydział Teologiczny, UO

\section{Ekumeniczny liturgista z pogranicza polsko-czesko-słowackiego}

Na gruncie krajów Grupy Wyszehradzkiej rzadko spotykamy badaczy naukowych jednakowo dobrze poruszających się w obszarze trzech krajów, języków i kultur. Zapewne w tym wąskim gronie znajduje się Walerian Bugel (ur. w 1968 r. w Koszycach na Słowacji). Ze względu na aktywność zawodową rodziców i zaistniałą wtedy sytuację geopolityczną rozpoczął naukę w polskiej szkole podstawowej w Żukowie Górnym, którą kontynuował w polskiej placówce w Czeskim Cieszynie oraz w tamtejszym Gimnazjum z Polskim Językiem Nauczania. Studia teologiczne odbył na Wydziale Teologicznym św. Cyryla i Metodego w Litomierzycach, które uwieńczył magisterium z teologii. W 1991 r. podjął studia trzeciego stopnia w Instytucie Ekumenicznym KUL, gdzie po dwóch latach, na podstawie rozprawy Wersje stowackie liturgii bizantyjskiej św. Jana Chryzostoma z lat 1976 i 1986. Studium teologiczno-liturgiczne, zyskał licencjat kanoniczny z teologii ekumenicznej. W 1998 r. na Wydziale Teologii KUL obronił pracę doktorską: Eklezjologia Unii Użhorodzkiej, napisaną pod kierunkiem o. prof. Wacława Hryniewicza OMI. Opublikowano ją dwa lata później w wydawnictwie KUL pod bardziej literackim tytułem: W obawie o własna tożsamość. Eklezjologia Unii Użhorodzkiej, Lublin 2000, ss. 242. Jej wersja czeskojęzyczna (Ekleziologie Užhorodské Unie a jejích dédiců na pozadí doby) ukazała się w 2003 r. 
Po ukończonych studiach doktoranckich pracował jako adiunkt w Katedrze Teologii Praktycznej Grekokatolickiego Wydziału Teologicznego Uniwersytetu im. P.J. Šafárika w Preszowie (obecnie Uniwersytet Preszowski) na Słowacji. Następnie w latach 19982016 był zatrudniony jako pracownik naukowy w projekcie badawczym: Zjednoczona Europa a chrześcijaństwo, zaś od 2003 r. jest adiunktem w Katedrze Teologii Liturgicznej Cyrylo-Metodiańskiego Uniwersytetu im. Palackého w Ołomuńcu. W międzyczasie (2002-2003) podjął pracę na Wydziale Pedagogicznym Uniwersytetu Hradec Králové. W tych uczelniach zlokalizowanych na terenie Czeskiej Republiki i Słowacji (Koszyce, Preszów) rozwijał swoją działalność badawczą, pisarską oraz organizacyjnodydaktyczną. Zarówno środowisko wzrastania, wykształcenie, miejsca studiów oraz zatrudnienie w ośrodkach naukowo-badawczych wskazują na bogaty językowo i kulturowo profil autora. Dobra znajomość rodzimych języków (czeski, słowacki, polski), wzbogacona angielskim, rosyjskim i niemieckim, dały mu dostęp do literatury specjalistycznej i zapewne znajdują odzwierciedlenie we własnych publikacjach.

Na bibliografię W. Bugela, po zyskaniu stopnia doktora nauk teologicznych, składa się ponad 100 publikacji. W jego dorobku są: 4 monografie i 1 słownik, 14 artykułów naukowych w periodykach recenzowanych (5 pol., 7 czes., 1 słow., 1 ang.), 51 rozdziałów w monografiach wieloautorskich ( 22 czes., 17 pol., 10 słow., 1 ang., 1 ros.), 13 thumaczeń tekstów teologicznych, 29 recenzji publikacji monograficznych, 6 skryptów i podręczników (wszystkie po czesku), 17 artykułów popularnonaukowych (w jęz. czeskim), współredakcja 14 monografii (13 czes., 1 ang.). Lektura dorobku pisarskiego autora pozwala wyróżnić kilka obszarów badawczych. Zasadniczo koncentruje się wokół zagadnień istotnych dla teologii ekumenicznej ${ }^{1}$, liturgii ${ }^{2}$, tra-

\footnotetext{
${ }^{1}$ Np.: Gtówne kierunki rozwoju ekumenii w Czechach, w: P. JASKóŁA (red.), Ekumenizm na progu trzeciego tysiaclecia. Materiały sympozjum ekumenicznego inaugurujacego działalność Instytutu Ekumenizmu i Badań nad Integracja na Wydziale Teologicznym Uniwersytetu Opolskiego, Opole 2000, s. 147-152; Katolicko-pravoslavné konsensy na celosvětové úrovni [Uzgodnienia katolicko-prawosławne na poziomie światowym], Velehrad 2001, ss. 98; Katolicko-pravoslavný dialog. Texty z let 19651995 [Dialog katolicko-prawosławny. Teksty z lat 1965-1995], Velehrad 2002, ss. 107; Ekumenické dimenze apoštolského listu Novo millenio ineunte [Dymensje ekumeniczne listu apostolskiego Novo millenio ineunte], w: Novo millenio ineunte: Pracovni seminár Katedry pastorální a spirituální teologie CMTF UP konaný dne 16. ř́jna 2002, Olomouc 2002, s. 60-67; Ekumeniczne doświadczenia Kościołów $w$ Czechach, w: L. GóRKa, S. PAWŁOWSKI (red.), Ekumeniczna odpowiedzialność na poczatku trzeciego tysiaclecia, Lublin, 2003, s. 65-74; Ekumenizm wewnętrzny w prawosławiu rosyjskim przykładem duchowości niepojednanych?, w: Ekumenizm duchowy - duchowość pojednania, Opole 2012, s. 207-236; The Papal Primacy as a Matter of the Ecumenical Dialogues [Prymat papieski jako przedmiot dialogów ekumenicznych], w: Pápežský primát v katolícko-pravoslávnom ekumenickom dialógu / The Primacy of the Pope in Catholic-Orthodox Ecumenical Dialogue, Súbor štúdií, Š. MARINČÁk (red.), [Orientalia et occidentalia. Analecta Instituti studiis spiritualitatis orientalium occidentaliumque provehendis nomine P. Michaelis Lacko Apellati, t. XIII], Košice 2013, s. 35-48.

${ }^{2}$ Wymieńmy przykładowo: Současné slovenské verze byzantské liturgie sv. Jana Zlatoústého [Współczesne wersje słowackie liturgii bizantyjskiej św. Jana Chryzostoma], Olomouc 2001, ss. 136; Obřady žehnání v různých liturgických tradicich. Colloqium liturgicum 2006 [Obrzędy błogosławieństw w różnych tradycjach liturgicznych], Olomouc 2006, ss. 102; Liturgická a eklesiální plurali-
} 
dycji cyrylo-metodiańskiej ${ }^{3}$ oraz patrologii ${ }^{4}$. Niemarginalnie zajmuje się także teorią i praktyką translatorstwa tekstów liturgicznych, w tym specjalistyczną terminologią teologiczną w obszarze bliskich sobie języków (czeski, słowacki, polski, angielski) ${ }^{5}$. W swojej działalności popularyzatorskiej nawiązuje do antropologii transkulturowej, kiedy podejmuje zagadnienia związane ze świętowaniem, życiem rodzinnym i współczesnymi problemami społecznymi ${ }^{6}$.

ta na území Československa v první polovině 20. toletí [Pluralizm liturgiczny i eklezjalny na terenach Czechosłowacji w pierwszej połowie XX w.], Olomouc 2011, ss. 219; Obřady manželství v různých liturgických tradicích [Obrzędy małżeństwa w różnych tradycjach liturgicznych], Olomouc 2013, ss. 186; Pohřební obřady v rùzných liturgických tradicích [Obrzędy pogrzebu w różnych tradycjach liturgicznych], Olomouc 2015, ss. 233.

${ }^{3}$ Na przykład: Cyrilometodějské papežské dokumenty z let 869-1985. Výběr [Cyrylo-metodiańskie dokumenty papieskie z lat 869-1985], Velehrad - Olomouc 2003, ss. 192; Kritéria určovania obradovej príslušnosti cyrilometodskej misie [Kryteria określania przynależności obrządkowej misji cyrylo-metodiańskiej], w: Duchovně, intelektuálně a politické pozadie cyrilometodskej misie před jej príchodom na Vel'kú Moravu. Monografia príspevkov z medzinárodného vedeckého symposia Nitra, 2. júl 2007, Nitra 2007, s. 90-103; Cyrilometodějské dědictví výzvou pro evropské integrační procesy i národni a konfesní tradice? [Dziedzictwo cyrylo-metodiańskie wezwaniem dla europejskich procesów integracyjnych oraz tradycji narodowych i konfesyjnych?], w: Kirilo-Metodievskoto kulturno nasledstvo i nacionalnata identičnost / Cyrilo-metodské kultúrne dedičstvo a národná identita [Kirilo-Metodievski studii, kn. 20], Sofia 2011, s. 60-75.

${ }^{4}$ Na przykład: Do akej miery je sv. Ján Zlatoústy pôvodcom Liturgie sv. Jána Chryzostoma? Niekol'ko systemizujúcich poznámok ku kritériám určovania autorstva najčastejšie používanej byzantskej liturgie [Na ile św. Jan Złotousty jest twórcą Liturgii św. Jana Chryzostoma? Kilka systematyzujących uwag na temat określania autorstwa najczęściej stosowanej liturgii bizantyjskiej], w: J. ZozULAK (red.), Život a dielo svatého Jana Zlatoústeho. Zborník príspevkov z vedeckej konferencie s medzinárodnou účastou Prešov, 23. 4. 2007, Prešov 2007, s. 83-94; Hlavni teologické důrazy paschálního kánonu Jana Damašského a byzantské velikonočni jitřni [Główne akcenty teologiczne kanonu paschalnego Jana Damasceńskiego oraz bizantyjskiej jutrzni paschalnej], w: V. HuŠEK, P. KiTZLER, J. Plátová (red.), Antické křestanství: liturgie, rétorika, antropologie. Sborník z konference Centra pro práci s patristickými, středověkými a renesančními texty a Patristické společnosti České Republiky (Olomouc 7.-8. listopadu 2008), Brno 2009, s. 53-68.

${ }^{5}$ Na przykład: Spôsob prekladu klúčových termínov pre byzantskú teológiu a duchovnost'v polskich pravoslávnych verziách CHR a BAS v porovnani s ich českými a slovenskými verzia$m i$ [Sposób tłumaczenia terminów kluczowych dla teologii i duchowości bizantyjskiej w polskich wersjach prawosławnych CHR i BAS w porównaniu z ich wersjami czeskimi i słowackimi], w: $\breve{S}$. MARINČÁK (red.), Problematika prekladov bohoslužobných textov do živého jazyka. Súbor štúdií, [Orientalia et occidentalia. Analecta Instituti studiis spiritualitatis orientalium occidentaliumque provehendis nomine P. Michaelis Lacko Apellati, t. VIII], Košice 2010, s. 27-52. M. STARowIEYSKI, Slovník raněkřestanské literatury Východu. Arabská, arménská, etiopská, gruzínská, koptská a syrská literatura, Červený Kostelec 2012, ss. 369 ; W. HRYNIEWICZ, Únia a uniatizmus v katolícko-pravoslávnom dialógu: Problémy, t’ažkosti a nádeje, w: Vybrané otázky a perspektívy teológie vo východných cirkvách zjednotených s Rímom / Selected questions and perspectives on the theology in the Eastern Churches united with Rome, Košice 2014, s. 361-390; T. VISI, Berakha (žehnáni, dobrořečeni) v židovské tradici, w: W. BugeL (red.), Obřady žehnání v různých liturgických tradicích, Olomouc 2006, s. 9-15; D.R. HoLeton, Žehnáni neživých předmétů a «nečlovéčich» bytostí v anglikánské liturgické tradici, w: W. BuGEL (red.), Obřady žehnání v různých liturgických tradicích, Olomouc 2006, s. 23-41.

${ }^{6}$ Przykładowo: Př́nos východni antropologie pro integraci Evropy [Wkład antropologii wschodniej w integrację Europy], w: S. RABIEJ (red.), Człowiek droga Europy: Z naukowej wspótpracy wydziałów teologicznych w Pradze, Trnavie i Opolu (Colloqiua Theologica nr 4), Opole 2004, s. 49-58; Společenská odpovédnost podniků v současné Evropě. Velehrad 3.-4.7.2005 [Odpowiedzialność 
Wśród wymienionych kierunków badawczych największa liczba publikacji naukowych związana jest z szeroko pojętą problematyką wschodniego chrześcijaństwa. W jej ramach autor omawia liturgie wschodnie, zwłaszcza tradycji bizantyjsko-słowiańskiej, unie kościelne, historię i duchowość katolickich Kościołów wschodnich, dysydenckie ruchy religijne w prawosławiu rosyjskim. Pokłosiem tych badań były dwie monografie: Současné slovenské verze byzantské liturgie sv. Jana oraz Ekleziologie Užhorodské unie a jejích dédiců na pozadí doby.

Od 2003 r., zatrudniony w Katedrze Teologii Liturgicznej, prowadzi zajęcia z liturgiki zachodniej. Znalazło to odzwierciedlenie w kilku jego czeskich publikacjach $^{7}$. Inne artykuły w tej grupie tematycznej dotyczą reformy soborowej - obrzędów Wiatyku (Viaticum v reformě 2. Vatikánského koncilu), wdrażania odnowy posoborowej w warunkach czechosłowackich (, Sacrosanctum concilium “ - initium culmenque instaurationis Ecclesiae? Kontekst i uwarunkowania historyczne wprowadzania reformy liturgicznej Soboru Watykańskiego II w warunkach czechostowackich) oraz urzeczywistniania liturgii na poziomie diecezjalnym (Liturgie partikulární církve). Natomiast jeden z nich stanowi dialog z socjologicznym ujęciem problematyki liturgicznej we Francji (Jak se (ne)stát obětí (pseudo)vědeckosti. Teologická dekonstrukce diskuse ke „kvazikněžské vrstvě”).

Do tego nurtu badań nad liturgią rzymską wpisuje się monografia: Anafora jako teologický text. Vybrané otázky na př́kladu pokoncilních eucharistických modliteb řmské liturgie (Anafora jako tekst teologiczny. Zagadnienia wybrane na przykładzie posoborowych modlitw eucharystycznych liturgii rzymskiej). Červený Kostelec: Pavel Mervart, 2015, ss. 316. Na jej treść rozmieszczoną w trzech rozdziałach składa się omówienie w porządku chronologicznym oficjalnych tekstów liturgicznych i innych ważnych dokumentów kościelnych dotyczących anafor posoborowych.

Już we Wstępie (ss. 14-15) Bugel referuje treść istniejących opracowań dotyczących problematyki anafor. Zaznacza, że nie chce powielać tych informacji, lecz wykorzystuje je w swojej analizie teologicznej całego tła procesu wprowadzania

społeczna zakładów pracy we współczesnej Europie], Olomouc 2008, ss. 140; Antropologia (dla i nie tylko) ludzi dobrej woli, w: S.C. NAPIóRKOWSKI (red.), Prorocy Europy Środkowo-Wschodniej XX wieku. Materiały III i IV Forum Teologów Europy Srodkowo-Wschodniej, Lublin 2009, s. 159-169; Mezi dekonstrukci krestanské liturgie a návratem k přirodním náboženstvím - náboženské obřady bezpopoveckých konfesné-obradnich skupin. Pokus o charakteristiku [Między dekonstrukcją liturgii chrześcijańskiej a powrotem do religii naturalnych - obrzędy religijne bezpopowskich grup konfesyjno-religijnych. Próba charakterystyki], w: K. ŽEŇUCHOvá (red.), Ludová próza na Slovensku v kontexte dejín slavistiky, Bratislava 2015, s. 295-336.

${ }^{7}$ Obřady žehnání v rüzných liturgických tradicích. Colloqium liturgicum 2006, Olomouc 2006, ss. 102; Liturgická a eklesiálni pluralita na územi Československa v první polovině 20. Století, Olomouc 2011, ss. 219; Obřady manželství v różnych liturgických tradicích, Olomouc 2013, ss. 186; Pohřebni obřady v rüzných liturgických tradicích, Olomouc 2015, ss. 233. 
anafor posoborowych. Pierwszy rozdział (s. 17-80) obejmuje okres od rozpoczęcia prac nad reformą ordo missae do $1970 \mathrm{r}$. Autor analizuje proces podziału kompetencji i wytworzenia specjalnych organów ds. reformy liturgicznej, prace związane z reformą Kanonu rzymskiego, motywy decyzji o zwiększeniu liczby anafor w liturgii posoborowej, aż po proces ustalenia kryteriów teologicznych dla nowych modlitw eucharystycznych. Ten rozdział zamyka omówienie znaczenia I Synodu Biskupów dla ostatecznego ukształtowania się liturgii mszalnej (s. 67-80).

Rozdział II (s. 81-158) omawia rozwój tytułowej kwestii w okresie następnych trzech lat (1970-1973). Daje to możliwość zreferowania sytuacji eklezjalno-społecznej wybranych krajów i regionów (Holandia, RFN, Belgia, Francja, Hiszpania, Czechosłowacja, kraje Ameryki Północnej i Łacińskiej). Podejmuje się oceny wybranych, nieautoryzowanych anafor (s. 111-133) oraz reakcji najwyższych władz kościelnych na fenomen stosowania niezatwierdzonych przez nie modlitw eucharystycznych (s. 134-158). Przeprowadzona przez autora analiza strukturalna i teologiczna dotycząca kluczowego słownictwa nie zawsze skłaniała go do zgody z ocenami i argumentacją teologiczną watykańskiej podkomisji eksperckiej.

Ostatni rozdział monografii zatytułowany Inkulturace EM a meśniho slaveni (s. 159-216), obejmuje treściowo proces powstawania dalszych anafor zatwierdzonych do użytku oficjalnego we kościelnych wspólnotach lokalnych. Autor referuje etapy wprowadzania nowych anafor poprzez poszczególne Konferencje Episkopatów, które zyskały zezwolenia na tworzenie wzbogaconych tekstów anafor. Omawia wyjątkową pozycję tzw. Kanonu szwajcarskiego (ss. 193nn) oraz anafory związane z inkulturacją liturgii rzymskiej dla Aborygenów, w tzw. liturgii zairskiej, wschodnioafrykańskiej liturgii z początku lat 70. oraz liturgii krajów azjatyckich, zwłaszcza Filipin i Indonezji (s. 203-216).

Wnioski z przeprowadzonych analiz autor zamieszcza w Zakończeniu monografii. Dosyć krytycznie ocenia prace watykańskich komisji eksperckich. Kwestionuje ich teologiczne kompetencje oraz zbyt arbitralną postawę wobec propozycji nowych anafor. Zarzuca też odpowiedzialnym za posoborową reformę liturgiczną brak pogłębionego rozumienia własnej tradycji liturgicznej, niespójność teologiczną i wybiórcze traktowanie faktów historycznych. Monografię wieńczy Aneks (s. 241-313) gdzie znajdujemy tłumaczenia (z komentarzami) tekstów 17 anafor. Pozwala to czytelnikowi zapoznać się bliżej z integralną treścią analizowanych anafor.

W sumie książka dra Waleriana Bugela realizuje nakreślony we Wstępie cel badawczy. Strukturalna, teologiczna i historyczna analiza posoborowych anafor została wzbogacona kulturowymi aspektami wprowadzania nowych treści. Cen- 
na jest też komparatywna analiza słownictwa teologicznego modlitw eucharytycznych $\mathrm{w}$ oryginalnych wersjach narodowych oraz przepracowanej łacińskiej (s. 197-203).

Oceniając dotychczasowy dorobek naukowy, zakładać należy, że W. Bugel będzie systematycznie rozwijał swoją działalność pisarską na obranych ścieżkach badawczych. Zapewne pozostanie wierny teologii systematycznej ekumenicznie zorientowanej oraz teologii pastoralnej z jej elementami liturgicznymi. Jego prace nadal będą wzbogacały myśl teologiczną w obszarze języka polskiego, czeskiego i słowackiego. 